Archived version from NCDOCKS Institutional Repository http://libres.uncg.edu/ir/asu/

\title{
Appalachľan
}

B O O N E, N O R T H C A R O L I N A

\section{History, Monumentality, And Interaction In The Appalachian Summit Middle Woodland}

\author{
By: Alice P. Wright
}

\begin{abstract}
The Middle Woodland period in eastern North America witnessed a florescence of monumental architecture and material exchange linked to widespread networks of ritual interaction. Although these networks encompassed large geographic areas and persisted for several centuries, extant archaeological models have tended to characterize Middle Woodland interaction as an historically unitary process. Using new data from the Garden Creek site in North Carolina, I argue that these frameworks obscure important historical shifts in Middle Woodland interaction. Recent collections-based research, geophysical survey, targeted excavation, and 14C dating (including Bayesian modeling) of this site reveal two coeval diachronic changes: a shift from geometric earthwork construction to platform mound construction; and a shift from the production of special artifacts (mica, crystal quartz) to the consumption of exotic artifacts in association with platform mound ceremonialism. These data hint at important changes in interregional relationships between the Appalachian Summit, the Hopewellian Midwest, and the greater Southeast during the Middle Woodland period, and provide a springboard for considering how processes of culture contact contributed to precolumbian cultural change.
\end{abstract}

Wright, A. (2014). History, Monumentality, and Interaction in the Appalachian Summit Middle Woodland. American Antiquity, 79(2), 277-294. doi:10.7183/0002-7316.79.2.277. Publisher version of record available at: https://www.cambridge.org/core/journals/american-antiquity/article/history-monumentality-andinteraction-in-the-appalachian-summit-middle-woodland/8A6ABDE3030E29F367568A0F24692AD9 


\title{
HISTORY, MONUMENTALITY, AND INTERACTION IN THE APPALACHIAN SUMMIT MIDDLE WOODLAND
}

\author{
Alice P. Wright
}

\begin{abstract}
The Middle Woodland period in eastern North America witnessed a florescence of monumental architecture and material exchange linked to widespread networks of ritual interaction. Although these networks encompassed large geographic areas and persisted for several centuries, extant archaeological models have tended to characterize Middle Woodland interaction as an historically unitary process. Using new data from the Garden Creek site in North Carolina, I argue that these frameworks obscure important historical shifts in Middle Woodland interaction. Recent collections-based research, geophysical survey, targeted excavation, and ${ }^{14} \mathrm{C}$ dating (including Bayesian modeling) of this site reveal two coeval diachronic changes: a shift from geometric earthwork construction to platform mound construction; and a shift from the production of special artifacts (mica, crystal quartz) to the consumption of exotic artifacts in association with platform mound ceremonialism. These data hint at important changes in interregional relationships between the Appalachian Summit, the Hopewellian Midwest, and the greater Southeast during the Middle Woodland period, and provide a springboard for considering how processes of culture contact contributed to precolumbian cultural change.
\end{abstract}

Durante el periodo Middle Woodland, la región este de América del norte experimentó una florescencia de arquitectura monumental e intercambio que fueron conectados a redes extensivos de interacción ritual. Aunque estas redes cruzaron regiones geográficas grandes y persistieron por varios siglos, modelos arqueológicos existentes han caracterizado interacciones Middle Woodland como un proceso histórico y unitario. Usando información nueva coleccionada del sitio de Garden Creek en North Carolina, argumento que estos modelos ocultan cambios importantes e históricos en las interacciones de la época Middle Woodland. Investigaciones recientes que utilizan colecciones, técnicas [prospección] geofísicas, excavación, y datos radiocarbónicos del sitio de Garden Creek revelan dos cambios contemporáneos y diacrónicos: el cambio de la construcción de montículos [de tierra] geométricos a la construcción de montículos plataformas; $y$ un cambio de la producción de artefactos preciosos (mica, cuarzo) al consumo de artefactos exóticos relacionados con ceremonialismo de montículos plataformas. Esta información indica que existieron cambios importantes en las relaciones interregionales entre el Sumo Appalachian, el mediooeste Hopewellian, y la mayoría del sureste durante la época Middle Woodland, y ofrezcan una punto de partida para la consideración de procesos de contacto entre culturas y su contribución a cambios en tiempos precolombinos.

$\mathrm{D}$ uring the Middle Woodland period, indigenous communities across eastern North America contributed to a florescence of monumental architecture, interregional exchange, and cosmologically meaningful material culture that has long captured the attention and imagination of archaeologists. In the Midwest, Middle Woodland mounds, earthworks, and exotic and iconographically distinctive ritual assemblages are called Hopewell. In the Southeast, contemporaneous traditions have been described as local versions of the wider Hopewellian phenomenon (Brose and Greber 1979; Seeman
1979), or, more recently, as a variety of regionally specific archaeological signatures, such as Kolomoki pattern platform mounds, Copena burial practices, and Swift Creek ceramic exchange networks. This taxonomic shift is the result of several decades of Middle Woodland research in the Southeast that have demonstrated considerable geographic variability among ceremonial practices that were once attributed to Hopewellian influences. While the broad synchronicity of Middie Woodland developments in the Midwest and Southeast led to its early depiction "as a period of panregional communality, we have come to

Alice P. Wright Department of Anthropology, Appalachian State University, ASU Box 32016, Boone, NC 28608-2016 (wrightap2@appstate.edu) 
realize that many diverse cultures were actually present, onto which a thin veneer of Hopewellian exchange, iconography, and ritual was overlain" (Anderson and Mainfort 2002:9).

That said, such formulations rarely address what sorts of on-the-ground mechanisms contributed to intercultural dynamics during the Middle Woodland period; put another way, they do not critically examine the ways by which certain dimensions of Hopewell came to "overlay" diverse southeastern traditions. To tackle these issues, archaeologists must critically evaluate the "Hopewell Interaction Sphere" concept (Caldwell 1964), which not only pre-supposes a unitary vision of interregional Hopewell, but also tends to characterize Hopewell interaction as something that happens to people, rather than a set of processes that people actively created and manipulated. An historical processual approach that emphasizes how convergences among diverse peoples relate to cultural change (sensu Alt 2006) is especially well suited to unpacking these issues. From this perspective,

history is defined as the ongoing process of making culture through social interactions. In this sense, history is never merely a chronicle or narrative of human experience, but rather a series of processes (e.g., diaspora, coalescence, and ethnogenesis) which, like all processes, are subject to comparison and generalization [Sassaman 2010:5; emphasis in original; see also Cobb 2005; Pauketat 2001].

In undertaking such a project, it is critical to keep in mind that, in addition to varying across space, Hopewellian interactions in the Southeast likely shifted through time. If, as suggested by Seeman (2004:58-59), midwestern Hopewell persisted across 13 generations, the chances that the many-times-great grandchildren of the earliest Hopewellian groups were interacting with exactly the same people, involved with exactly the same interregional networks, or executing ceremonies according to the exact same script as their predecessors are rather slim. Similarly, the ways that Southeastern peoples engaged or did not engage with Hopewellian and other nonlocal objects and ideas could have changed dramatically through time. Depending on particular geographic and historical contingencies, Southeastern involve- ment with Hopewell may have varied from hesitant acceptance or enthusiastic adoption, from the mutual creation of a hybrid set of ritual or exchange practices, to polite rejection and even pronounced resistance.

An historical processual examination of the Hopewellian Southeast first requires the empirical identification of intercultural interaction and, by extension, Middle Woodland culture-making. To that end, this article presents new information from the Garden Creek site in western North Carolina's Appalachian Summit, and offers a diachronic narrative of the emergence of different forms of monumental architecture and the production and use of artifacts involved in Middle Woodland interaction networks. Although evidence from Garden Creek has previously been cited to support various models for Middle Woodland interaction, new data produced through geophysical survey, targeted excavation, and radiometric dating indicate that the interpersonal nature and geographic orientation of interregional connections underwent substantial transformations in the first several centuries A.D. In short, a chronologically dynamic record of monumentality, craft production, and exotic material culture at Garden Creek allows for the provisional inference of several processes of intercultural contact that shaped and were shaped by Middle Woodland people in the Appalachian Summit. Rather than characterizing these diverse material remains as an "overlay" of interregional influences, this historically minded account underscores the potential multiplicity of interaction experiences in the Middle Woodland Southeast, and calls attention to the agency of local constituencies in the negotiation of intercultural connections.

To frame the historical processual approach adopted in this article, $\mathrm{I}$ begin with a discussion of extant perspectives on Middle Woodland interaction in the Southeast. Although several different models have emerged over the years, this brief history shows that they have tended to be applied to the Middle Woodland archaeological record with a fairly broad brush, with little to no consideration of temporal variability. I propose that instead of deploying these static frameworks for interregional interaction during the Middle Woodland period, we generate detailed diachronic histories of particular places to see if, when, and 
how particular scenarios played out. Focusing on architectural, artifactual, and temporal data from the site's Middle Woodland monuments, I attempt to carry out precisely this sort of project at Garden Creek. The resulting narrative, though specific to this site and its historical contingencies, suggests that diverse forms of interregional culture contact are important historical processes to critically and creatively investigate across the Middle Woodland Southeast and beyond.

\section{Archaeologies of Southeastern Hopewell}

According to James Griffin, one of the forefathers of Eastern Woodlands archaeology, the seminal 1978 conference on Hopewell archaeology in Chillicothe, Ohio amounted to a "revolt of the South" (Pacheco 1996:vi). Contrasting with most of the previous century of Hopewell scholarship, the Chillicothe Conference expanded the discussion of exotic artifacts, ceremonial practices, and monuments dating to the Middle Woodland period beyond the Ohio Valley and into the greater Midwest and Southeast. However, this interregional free-for-all was not unproblematic. Bennie Keel, who chaired the presentation of papers on southeastern states, opened the follow-up discussion by noting "that in a strict sense, there was no Hopewell in the Southeast" (Brose and Greber 1979:209). Yet if that was the case, why was that region addressed at the conference at all?

The short answer is that for many decades, archaeological research at Middle Woodland sites in the Southeast had yielded artifacts and exotic raw materials that were (and, in most cases, still are) commonly associated with Hopewellian ceremonialism. Though exact assemblages varied from site to site, they included Hopewellian ceramics and figurines; copper panpipes, earspools, breastplates, and pins; cut and uncut sheet mica; and various other diagnostic stone, shell, and bone objects (see chapters in Brose and Greber 1979). The earliest interpretations of these assemblages were decidedly diffusionist. The most profound interregional influences were thought to have been directed toward the Southeast from the Hopewell core, though it was also suggested that a small number of traits may have diffused from south to north (e.g., Greenman 1938; Sears 1962; Shetrone 2004 [1930]). This diffusion of traits was linked to widely shared religious beliefs and ceremonial practices (Caldwell 1964) that in turn were viewed as a realm of activities entirely separate from everyday "domestic" life.

By the 1970s, archaeologists were striving to delineate a mechanism for widespread Hopewell material culture that was grounded in economic rationale. Stuart Struever and Gail Houart (1972) argued that the Hopewell Interaction Sphere was an exchange system, comprised of specialized production and ceremonial facilities in Ohio and subsidiary transaction centers associated with farflung raw material sources. Slightly later, David Braun (1986) proposed a peer polity framework, which postulated that Middle Woodland community members would seek out exotic objects in the context of competitive display. Mark Seeman (1995) revised and elaborated upon these ideas, arguing that Hopewellian material culture and iconography was an interregionally intelligible form of communication that could be used by incipient leaders to acquire authority and prestige.

Today, a combination of Seeman's ideas and Mary Helms's (1988) perspectives on exotic material culture defines the predominant view of southeastern Hopewell, which emphasizes the potential utility of nonlocal artifacts in contexts of aggrandizement. As David Anderson (1998:287) explained,

by being major players in the Hopewellian world, the principals at these [southeastern] centers could have been perceived as having esoteric knowledge....and this, plus their control over desirable wealth items, may have inspired people to their service over wide areas and at the same time led to their sanctification.

One correlate of this framework has been the identification of gateway centers for interregional exchange along likely transportation corridors (Keith 2013; Ruby and Shriner 2005).

While different in many ways, these diffusionist, economic, and sociopolitical scenarios tend to presuppose an historical unity to interregional Hopewell. By this, I mean that each of these frameworks is at least implicitly presented as the way that Hopewellian interaction transpired at a particular locality throughout the Middle Woodland period. For example, in the Appalachian Summit, evidence for Hopewell interaction has 
been attributed to trade with Ohio Hopewell travelers who were in the area to procure mica (Chapman and Keel 1979), or to aggregations among local communities and representatives from the Hopewell core at particular ceremonial encampments (Walthall 1985), or to efforts by southeastern leaders to integrate their communities through feasting and exotic gift giving (Knight 2001). The possibility that multiple mechanisms of interregional interaction may have taken place at a single site-either simultaneously or sequentially--is rarely addressed.

The following case study aims to explore precisely this issue by establishing detailed diachronic narrative of interregional interactions experienced at the Garden Creek site. Specifically, I propose that different forms of monumental architecture and diverse artifact assemblages represent critical shifts in the ways in which interregional interactions were brought to bear on the creation of culture and unfolding of history at Garden Creek. In this regard, the present study brings the discourse on southeastern Hopewell full circle, being grounded in an important insight offered early on by Joseph Caldwell [1964:143]:

The explanation then for a positive correlation between interaction and innovation is that when different cultural traditions are brought together there becomes available to each a new supply of diverse forms upon which new rearrangements of forms -innovations and inventions-can be built.

\section{Middle Woodland Investigations at the Garden Creek Site}

The Garden Creek site is located on a small (less than 25 ha, approximately) terrace and floodplain along the Pigeon River in the Appalachian Summit, where the Middle Woodland period is subdivided into the Pigeon phase ( $300 \mathrm{cal} \mathrm{B.C}-$ A.D 200 ) and the Connestee phase (200-600 cal A.D. ), largely according to differences in ceramic assemblages. The site's most extensive occupations resulted in two more-or-less spatially discrete components dating to the Mississippian and Middle Woodland periods, respectively. The latter includes two or three mounds $(31 \mathrm{Hw} 2,31 \mathrm{Hw} 3$, and the newly discovered Mound No. 4; see Hors- ley et al. 2014) and remains of non-mound activities $(31 \mathrm{Hw} 8)$ (Figure 1). This portion of the site has been investigated intermittently by antiquarians and archaeologists since the late nineteenth century.

Two field projects are relevant to the present study. The first, directed by Bennie Keel, involved the systematic documentation of the site as it existed in the mid-1960s and the total excavation of Garden Creek Mound No. 2, which was threatened by encroaching residential development (Keel 1976). Keel's efforts revealed multiple stages of mound construction, an underlying midden, and features and artifacts indicative of communal ceremonialism and extralocal exchange. Specifically, nonlocal pottery, ceramic figurines, and certain exotic artifacts were cited as evidence that the people of Garden Creek participated to some degree in extralocal Hopewellian interaction networks (Chapman and Keel 1979; Keel 1976; Walthall 1985). Based on his seminal ceramic chronology for the Appalachian Summit and a single radiocarbon date from the top of the mound (1145 \pm 85 B.P. [Eastman 1994:66]), Keel (1976:86) assigned Mound No. 2 to the late Middle Woodland Connestee phase. He also suggested that the scatter of artifacts that surrounded the mound represented a contemporaneous village occupation, although his efforts (Keel 1976:71) to characterize this area through surface survey were hampered by houses and established lawns.

The second field project of interest, which I directed in 2011-2012, targeted this off-mound component. Nearly 50 years after Keel's fieldwork, the neighborhood had expanded considerably, eliminating the possibility of surface-level archaeological survey and mapping, and restricting opportunities for extensive excavation. However, by combining shallow archaeological geophysics with highly targeted excavations, the Garden Creek Archaeological Project (GCAP) managed to maximize data recovery across almost the entirety of the western half of the landform with minimal disturbance to the site and its modern day occupants.

To briefly summarize our field methods, we employed several complementary techniques to measure subsurface geophysical variability and to identify anomalies indicative of past human activity (for more details, see Horsley et al. 2014). 


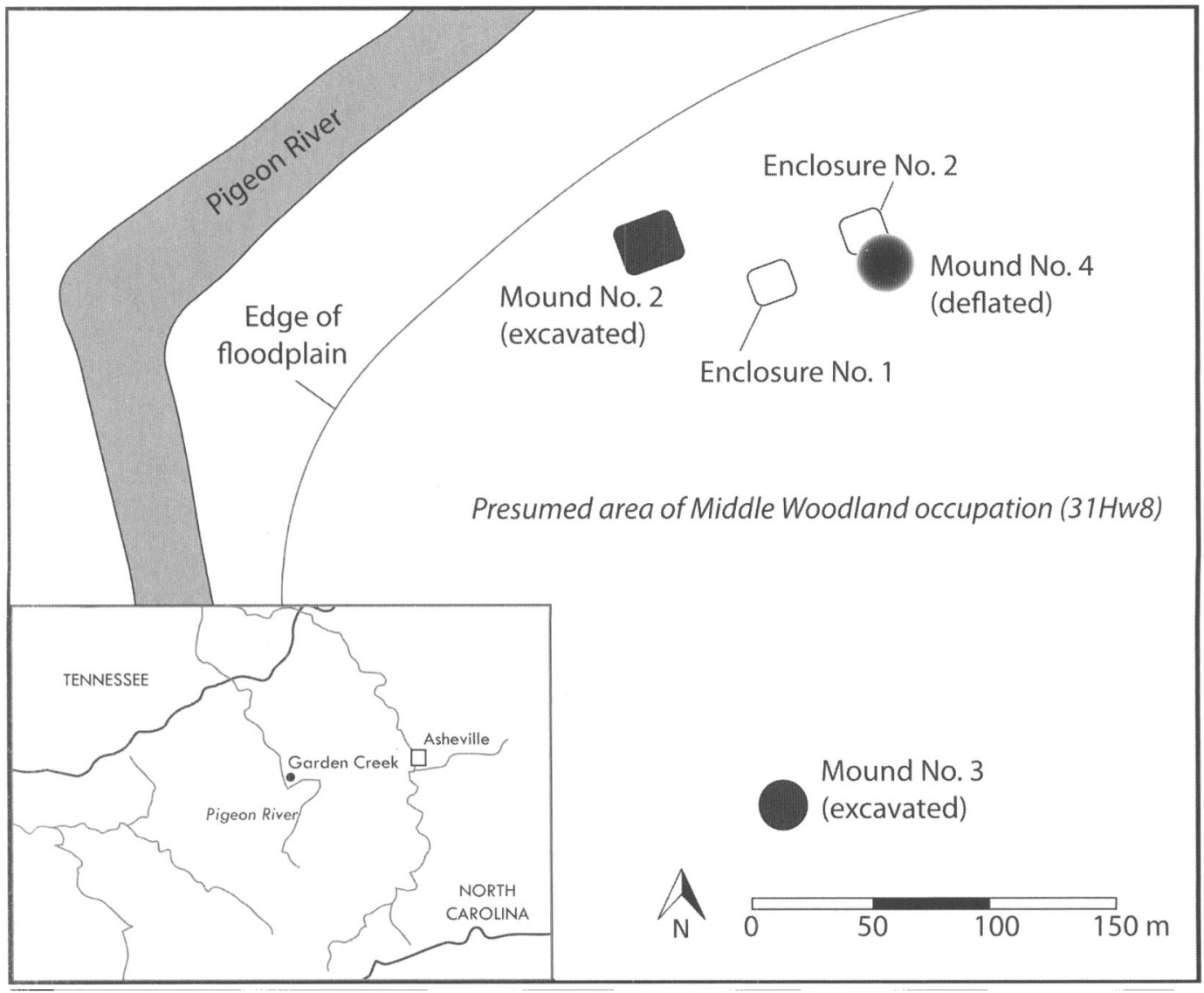

Figure 1. Schematic map of the Middle Woodland component Garden Creek site. Inset shows location of Garden Creek in the greater Appalachian Summit.

Using a Bartington single-axis magnetic field gradiometer, we surveyed approximately 7 ha of the Middle Woodland portion of the site, including large portions of the landform that were not subsumed by the proposed boundaries of Keel's Middle Woodland village. Nearly 1 ha of this survey area was also mapped using ground penetrating radar (GPR). These efforts identified numerous negative features (e.g., pits, pit hearths, large postholes). Based on the spatial distribution of these anomalies and the results of limited ground truthing, we have provisionally attributed much of the off-mound remains to intermittent occupation, perhaps associated with the seasonal aggregation of Middle Woodland groups whose subsistence regimes included hunting, gathering, and gardening (Ward and Davis 1999:154).

Two linear features, each in the shape of a rectangle with rounded corners, stand out among these anomalies (Figures 2, 3). Labeled Garden
Creek Enclosures No. 1 and No. 2, they resemble small geometric enclosures common in midwestern Adena and Hopewell contexts, particularly so-called "squircles" (Anderson 2013: 252-253; see also Burks and Cook 2011; Clay 1987, 1998). From inside edge to inside edge of the linear magnetic signatures, these features measure 18 $\mathrm{m}$ southwest-to-northeast and $16 \mathrm{~m}$ northwestto-southeast; the outline of each is broken by an opening or "gateway" that measures about $4 \mathrm{~m}$ wide. In plan view the anomalies are slightly offset, but their gateways generally face in the direction of the opposite enclosure. Moreover, the enclosures share the same orientation, approximately 20 degrees west of magnetic north, suggesting a purposeful layout that perhaps references some presently undetermined geographic or celestial alignment. As discussed below, these features were further elucidated through targeted excavation of Enclosure No. 1. 


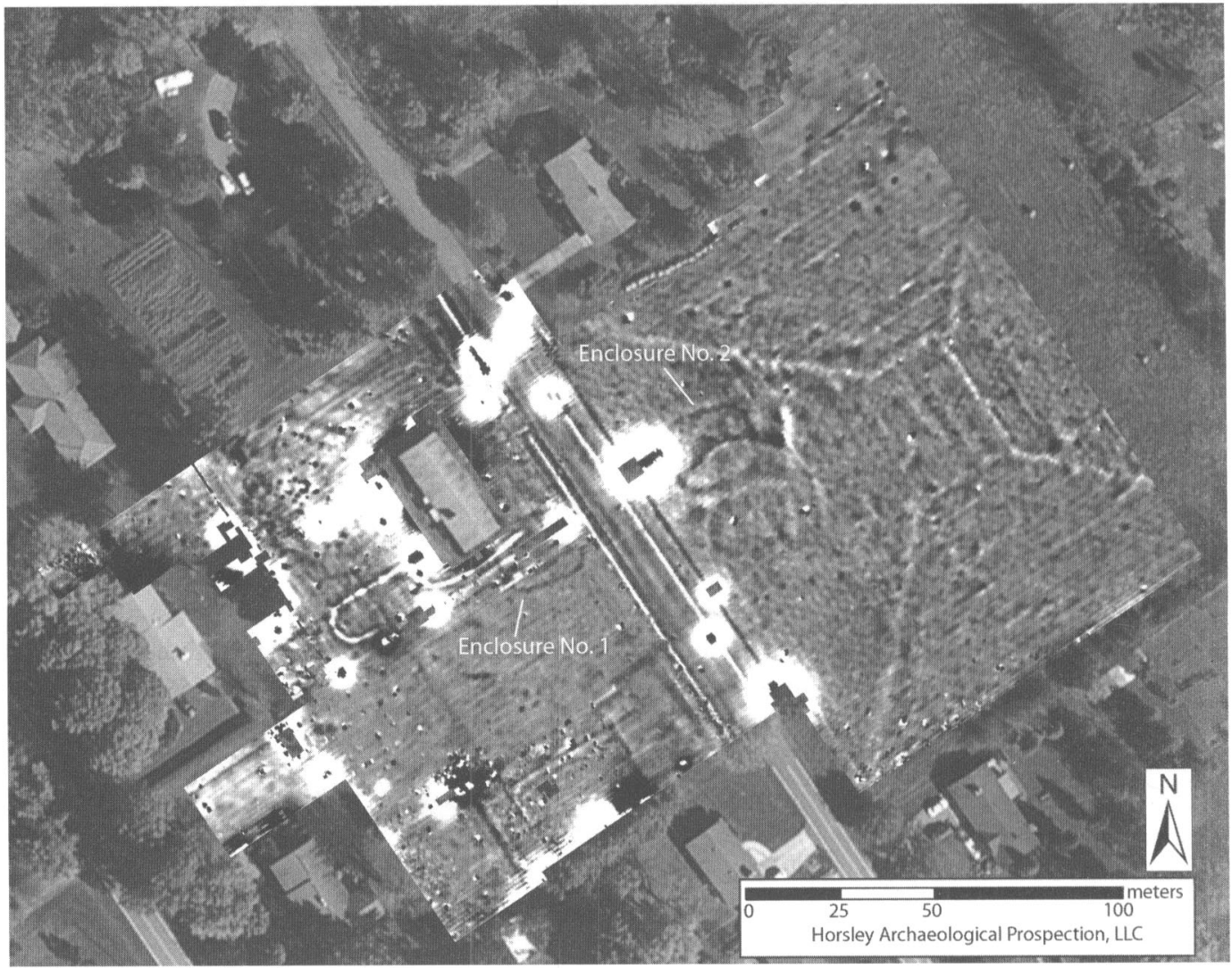

Figure 2. Extract of the Garden Creek magnetometer data revealing anomalies representing Enclosures No. 1 and No. 2, Other archaeological features are also suggested, as well as disturbances associated with modern features (e.g., iron metal, septic systems), and agricultural activities (plow scars). Results are plotted from -12 nT (white) to +12 n'T (black). Processing was limited to clipping to within $30 \mathrm{nT}$, application of zero mean traverse, and interpolation to a resolution of $.25 \mathrm{~m} \times .125 \mathrm{~m}$.

In short, old and new fieldwork at Garden Creek has generated a record of monumentality and material culture that points to similarities and, by extension, interaction with Hopewellian peoples in the Midwest. By examining these monuments and their associated assemblages in more detail, I argue that it is possible to delineate not simply participation in so-called Middle Woodland interaction spheres, but more specifically the intensity, directionality, and temporality of local communities' relationships with foreign people and places.

\section{Stratigraphic Histories of Garden Creek's Monuments}

As important elements of Garden Creek's built environment, Mound No. 2 and Enclosures No. 1 and No. 2 have considerable potential for elu- cidating the construction history of the site and revealing significant architectural changes that may be related to interregional interactions and/or local developments (Beck et al. 2007). In particular, architectural information derived from the stratigraphy of these monuments can be compared to the architecture of broadly contemporaneous monuments in other regions as a means of identifying significant consistencies and divergences in monumental practice at different moments throughout the Middle Woodland period.

\section{Mound No. 2}

When Keel encountered Mound No. 2 in 1965, it was already partially destroyed by a bulldozer. Fortunately, his detailed excavation of the remaining mound in reverse stratigraphic order allows for the formulation of a fairly detailed life history of the monument. Keel assigned all mound con- 


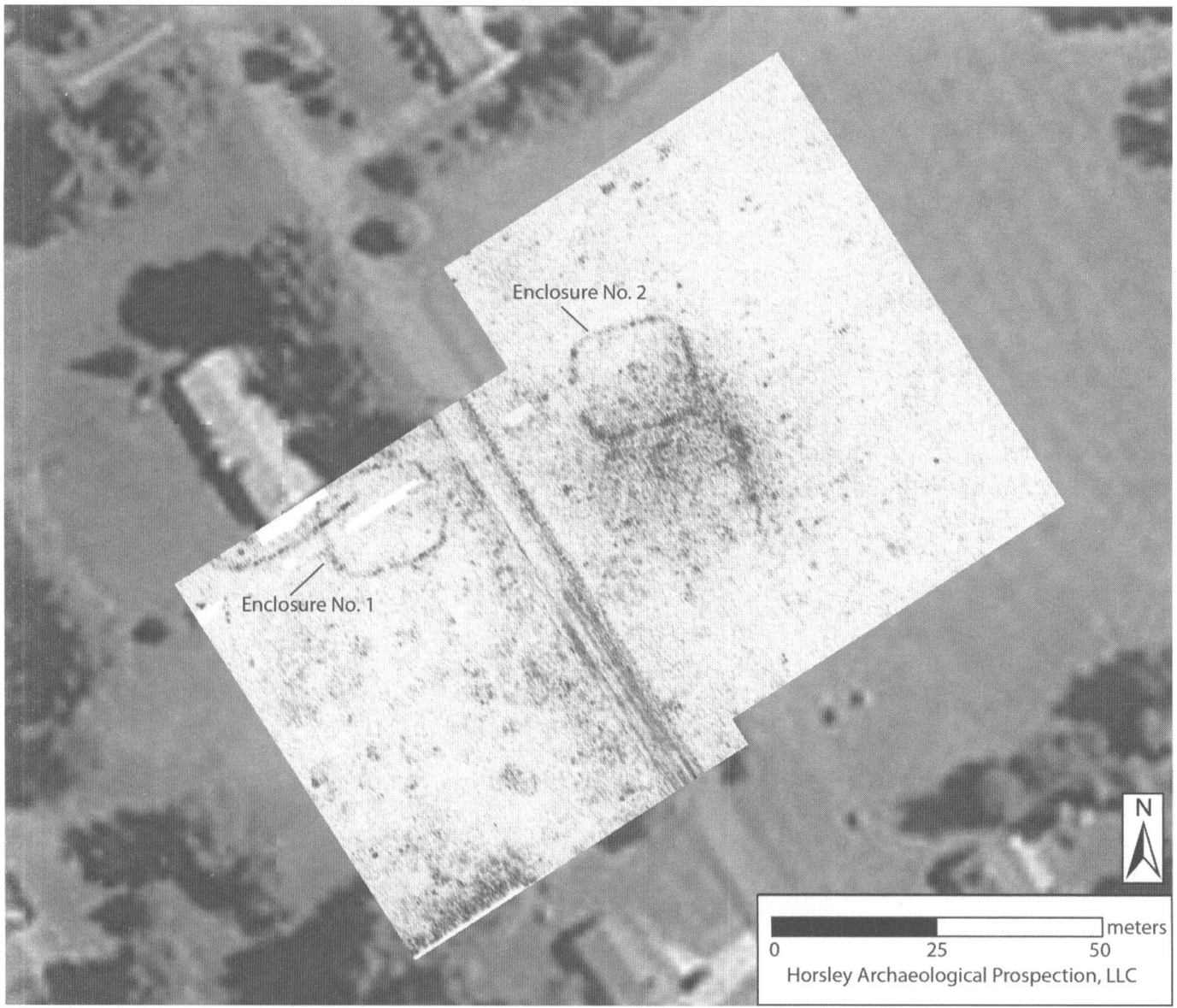

Figure 3. GPR amplitude time-slice of Garden Creek Enclosures No. 1 and No. 2, corresponding to approximately 1.0$1.2 \mathrm{~m}$ below the present ground surface. Time-slices were produced from individual radargrams after gain correction, constant background removal, and the application of a bandpass Butterworth filter to limit the frequency response to between 160-500 MHz. Strong reflections are purple.

struction stages and associated features to the late Middle Woodland Connestee phase, based largely on pottery associations. However, because the chronological relationships among Woodland ceramic series in the Appalachian Summit are poorly understood (Ward and Davis 1999), stratigraphic relationships and new radiocarbon dates (see below)-not ceramic affinities - are considered the most reliable sources of chronological information at Mound No. 2.

The earliest evidence of activity associated with Mound No. 2 consists of several features that were dug into the subsoil and were subsequently capped by a midden and, later, by the mound itself. Keel also identified and mapped nearly 1,300 postholes at the level of the subsoil, including a rectangular outline designated Struc- ture 1. The posts from Structure 1 were removed before the resulting holes were filled with a clean, white sand; elsewhere, I (Wright 2013) have suggested that this pattern represents the purposeful dismantling of this building, and perhaps its ritual closure. Pre-mound activity continued in this location, producing a dark clayey midden that ranged between about 9 and $21 \mathrm{~cm}$ thick (Keel 1976:77), in which Keel encountered cobble hearths, basins, and numerous postholes. The thickness of the midden suggests that the activities that produced it were either intense or prolonged. The possibility that it represents the remains of a domestic occupation cannot be ruled out (Wright 2013), but certain lines of evidence - such as a mica-lined pit at the base of the pre-mound midden and the possible ritual closure of Structure 
1-suggest that ceremonially prescribed activities may have occurred there as well.

The first episode of mound construction directly overlay this midden. Measuring about 12 by $18 \mathrm{~m}$ in horizontal extent and about a half-meter tall, this low platform was a locus of diverse activities, as indicated by the presence of many different types of features - shallow basins, deeper pits, hearths with and without cobbles, and a pipestone cache-and numerous postholes. Some of these posts appear to have formed a rectangular outline around a burned surface (Feature 41) that Keel identified as the floor of a mound-top structure. As a result of plowing and bulldozing, the absolute summit of the second stage of Middle Woodland construction was not intact, but considerable information was gleaned from the surface represented by the interface of the plowzone and the secondary mound fill. Like the summit of the primary mound, this surface was characterized by diverse features, though no structures were identified among the postholes at this level.

This record of platform mound architecture and activity at Garden Creek is similar to a number of other Middle Woodland platform mounds in the Southeast. Concentrated in the deeper South, the so-called Kolomoki pattern of platform mound architecture is defined by a number of characteristics (Knight 1990:170-171): irregular scatters of postholes (attributable to scaffolding behavior; see Knight 2001:319) and pits; a lack of clear summit structures; extraordinarily large postholes, some with insertion and/or extraction ramps; burned areas and hearths on mound summits; multi-stage construction using multicolored fills; and the presence of exotic artifacts and special ceramics. Garden Creek Mound No. 2 exhibits all of these traits, with the possible exception of the lack of clear summit structures. Vernon J. Knight (2001:221; see also Jefferies 1994) interprets these patterns as the remains of "intermittent, repetitive activities involving manipulation of exotic artifacts, caching of goods in small pits, food preparation and consumption, frequent scaffolding of objects unknown, and monumental display of poles." Because these activities were associated with earthen platforms that were periodically resurfaced with new construction episodes, Knight (2001:328) further argues that these contexts represent ceremonial practices "centered on world renewal and feasting, emphasizing community integration" (see also Hall 1997). While Knight (2001:327; see also Lindauer and Blitz 1997) suggests that these activities operated at a relatively local, intraregional scale to facilitate and secure intervillage alliances, the widespread adoption of such architectural practices across what are now several states suggests that some form of interregional interaction occurred among those communities erecting Kolomoki pattern mounds.

\section{Enclosure No. 1}

In a 5-x-3-m horizontal excavation block and two 1-m-wide profile trenches, the Enclosure No. 1 anomaly was revealed to be a steep-sided ditch with nearly flat walls and a flat bottom that extended 1 to $1.2 \mathrm{~m}$ below the ground surface. ${ }^{1} \mathrm{In}$ profile, the shape of the ditch was generally trapezoidal, measuring $1.55 \mathrm{~m}$ wide at the top (below the plowzone) and $80 \mathrm{~cm}$ wide at its base. The entirety of the sub-plowzone ditch was originally excavated into very dense sandy clay subsoil, but it was eventually filled in with three distinct zones of sediment. No macroscopic evidence of soil formation was noted at any of the interfaces between zones of fill, suggesting there were no major gaps in episodes of infilling.

Interestingly, the life history of Enclosure No. 1 does not appear to have ended with the infilling of the ditch. Once it was entirely filled in, the outline of the enclosure continued to be marked by a series of posts that ranged from 12 to $23 \mathrm{~cm}$ in diameter and aligned roughly with the middle of the original ditch. Eventually, these posts were removed and the resulting postholes were filled with tightly packed river cobbles and, in some cases, a few fragments of pottery, charcoal, and mica. These features were encountered during excavation as discrete columns of rock, beginning at the base of the plowzone and extending though the top, middle, and sometimes bottom zones of ditch fill (Figure 4). In total, 6 rock-filled postholes were identified across a 5-meter-long exposure of the ditch, spaced at $80-\mathrm{cm}$ intervals; additional rock-filled postholes were identified in separate $1-m$ profile trenches, suggesting that this alignment continued around the entire enclosure.

In many regards, the architecture of Enclosure No. 1 is remarkably similar to a category of mon- 


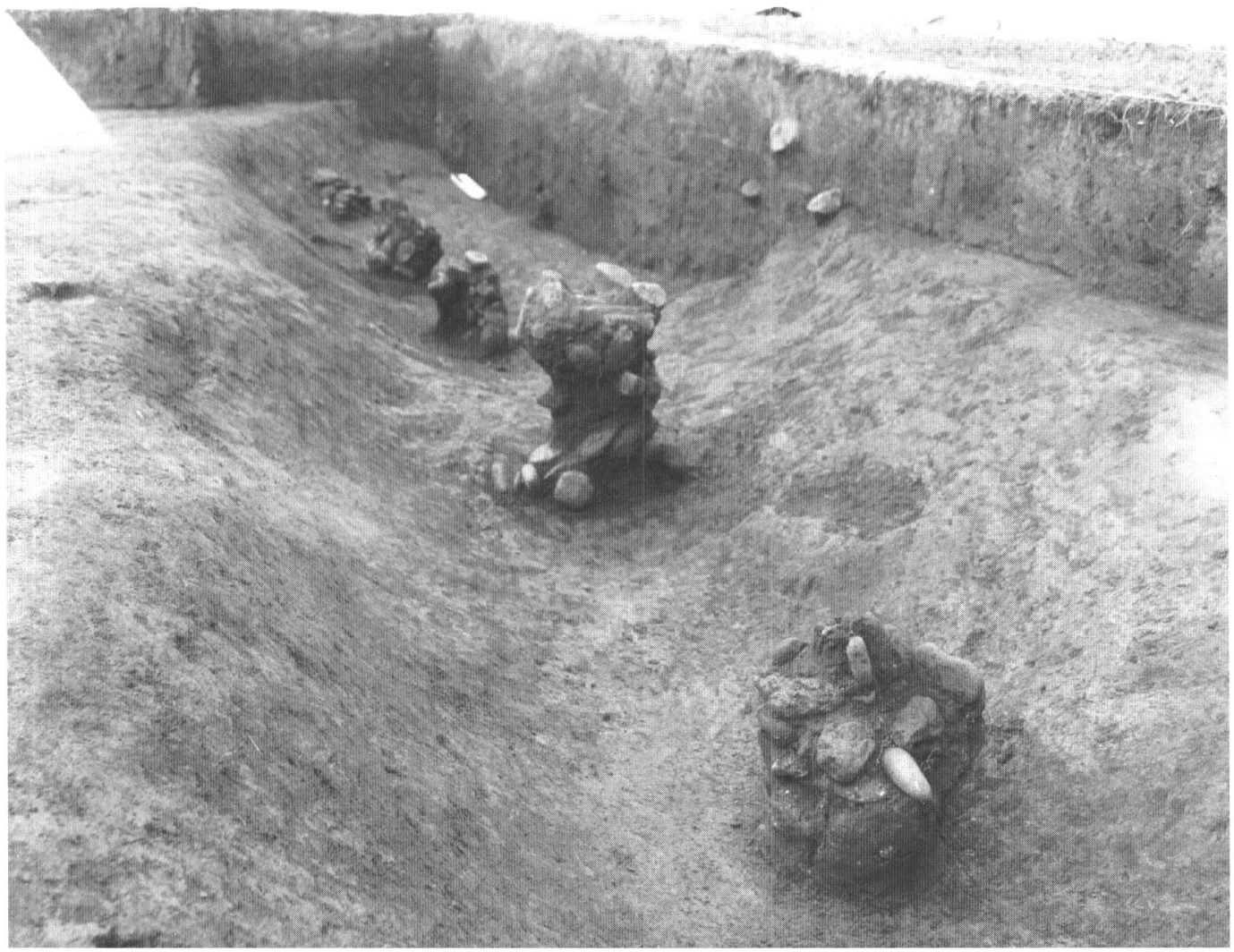

Figure 4. Rock-filled postholes at the base of the top zone of ditch fill in Enclosure No. 1.

uments common in the Ohio Valley called small geometric enclosures. Sometimes referred to as the Mt. Horeb tradition (Byers 2004; DeBoer 1997) or Adena sacred circles (Webb and Snow 1945), these earthworks are much smaller than massive ditches and embankments that serve to demarcate monumental sites around the SciotoPaint Creek confluence, and as a result, they have likely suffered far greater effects from erosion and plowing. Nevertheless, they are noted with some frequency on early maps of the greater Ohio Valley (e.g., Squier and Davis 1998 [1848]), both in association with and away from larger earthwork complexes. Though historically associated with the Early Woodland period and the Adena complex, "It is now recognized that the Mt. Horeb tradition not only largely defines the later Early Woodland period but also extends into the Middle Woodland in limited parts of this region [the Central Ohio Valley], terminating around AD 250" (Byers 2004:28-29).
Using published and unpublished literature from the Middle Ohio Valley, Richard Jefferies, George Milner, and Edward Henry (2013:103104) recently identified 259 of these small geometric enclosures from which they extrapolated the general characteristics of this type of monument. ${ }^{3}$ Ranging from .01 to 1.35 ha in the amount of space enclosed, most of the earthworks in their sample were circular, though arcs, ovals, and rectangles were also present. Openings or gateways in the earthworks were also commonusually one opening per enclosure, most often facing east. In a similarly comparative study (Wright 2013), I used Byers's (2004) typology to classify 88 enclosures according to their vertical characteristics: 38 consisted of an embankment with no ditch (K-profile); 49 included both and embankment and a ditch (47 with an interior ditch/SR-profile, 2 with ditches inside and outside the embankment); and one had a ditch but no embankment. Anecdotally, the few enclosures 
that have been excavated are characterized by particular stratigraphic patterns, including the use of sediments from specific locations and exhibiting specific properties (e.g., color). The careful selection of building materials has been interpreted not only as evidence of architectural engineering (sensu Sherwood and Kidder 2011), but also in reference both to symbolic design principles apparent in other Hopewell structures and objects (Greber 2006:90) and to "the Hopewell people's efforts to manage the spirit world" (Lynott 2004:6).

All that said, Garden Creek Enclosure No. 1 is distinctive from its Ohio Valley counterparts (at least those that have been excavated) in at least one important way-it was filled in and effectively erased from the landscape probably not long after it was initially constructed. Such activity has not been observed at any small geometric enclosure in the Ohio Valley, though it seems likely that many of these enclosures remain to be discovered through geophysical survey (Burks and Cook 2011); their subsequent study may affect this apparent pattern. At present, however, the ceremonial and social activities that led to the erasure of the Garden Creek enclosures are events that are unique to this locality and indicative of specific historical events.

\section{Artifact Assemblages in Monumental Contexts}

On the basis of the earthen architecture itself, interregional connections to the south (the Kolomoki pattern) and the north (AdenaHopewell small geometric enclosures) can already be identified at Garden Creek. The nature of these interactions can be clarified by considering certain artifact assemblages from these contexts in greater detail.

Both monuments yielded artifacts that traditionally have been associated with Hopewellian ceremonialism. Compared to other Middle Woodland deposits at Garden Creek, the fill of Enclosure No. 1 was remarkable for its high density of cut sheet mica fragments and crystal quartz debitage (Wright and Loveland 2013). Although both raw materials are locally available in the Appalachian Summit, finished artifacts such as mica cutouts or stylized crystal quartz bifaces are rare in the region, and none have been recovered from Garden Creek. However, the Summit has long been assumed to have been the raw material source for such objects recovered at Ohio Hopewell ceremonial sites (e.g., Griffin 1967; Holmes 1919). Given these connections, it is possible that the mica and crystal quartz debris recovered from the ditch represents the transformation of local raw materials into partially or wholly finished objects for some sort of extralocal transaction-in short, the remains of Hopewellian craft production. This interpretation is strengthened by the unique and fairly direct association of these materials with Enclosure No. 1 (for details, see Wright and Loveland 2013). The presence of several large but fragile sheets of mica $(8-11 \mathrm{~cm}$ on a side) indicates that these scraps were directly deposited into the ditch as it was being filled with earth and other materials, suggesting in turn that cut mica craft production was somehow associated, spatially and/or symbolically, with the enclosure itself.

Mound No. 2's assemblage of diagnostically Hopewellian material culture is quite different. This relatively small assemblage includes blades made of Ohio Flint Ridge chalcedony, ceramic figurines, copper beads, sheets, and pins, and cut animal mandibles. In contrast to the mica and crystal quartz from the enclosure, the provenance of the blades is not local; it is also possible that the copper artifacts originated from distant regions (Ehrhardt 2009). Importantly, these artifacts are finished objects, and there is no on-site evidence for their production. In this regard, the Hopewellian artifacts associated with Mound No. 2 appear to represent the targeted consumption of ceremonial material culture, rather than the production of such items as seen at Enclosure No. 1. Insofar as these objects may have derived value from nonlocal origins or associations, it seems plausible that they were used in mound related activities to reference or cite foreign people, places, or practices, and as such, that they might have been sources of ritual power or authority for their possessors (Helms 1988).

Whereas these Hopewellian assemblages suggest that certain dimensions of sociality at Garden Creek related to long-distance connections, the ceramic artifacts from both monuments highlight the active contributions of a local constituency. 
The vast majority of ceramics from Enclosure No. 1 and Mound No. 2 can be assigned to local ceramic series, characterized by sand and crushed quartz tempers and a variety of surface treatments (Keel 1976). Even sherds from the mound that were initially thought to have originated in Ohio on account of their rocker-stamped surface treatment (Keel 1976:197) are now known to have been made locally (see petrographic analysis by Stoltman 1999). Only .21 percent of sherds from the ditch $(n=475)$ and .25 percent of sherds recently reanalyzed from the mound $(n=7,420)$ exhibited nonlocal limestone tempers; these artifacts probably originated in eastern Tennessee. Meanwhile, in his analysis of nearly 12,000 sherds from Mound No. 2, Keel (1976) identified five "Georgia type" sherds (Early Swift Creek Complicated Stamped and Napier Stamped) and one "Florida type" sherd (Crystal River Plain) in addition to 92 limestone-tempered sherds from Tennessee. In short, while it is demonstrably true that pots are not people, these macroscopic (and thus preliminary) data indicate that the ceramic assemblage at Garden Creek is overwhelmingly attributable to production and, presumably, to use by local people.

Arguably, despite their extralocal associations, the Hopewellian assemblages at Garden Creek can also be interpreted as the results of activities carried out by local people. The materials and tools necessary for mica and crystal quartz crafting were locally available, and mica in particular requires little specialized skills for its manufacture into cutouts (Spielmann 2009:184). In fact, the wide distribution of mica fragments at Middle Woodland sites across the Eastern Woodlands has been cited as evidence that mica crafting was not limited to ritual specialists and could be carried out away from Ohio Hopewell ceremonial precincts (Spielmann 2009:181-182). We can also infer local deployment of nonlocal traditions from the Hopewell style potsherds made with Appalachian Summit paste and tempers. While the introduction of these distinctive surface treatments to the Garden Creek vicinity plausibly involved some material or interpersonal exchange, the vessels themselves were most likely manufactured by local potters, using local techniques. In contrast, the few patently Hopewellian artifacts and nonlocal ceramics found in the mound can, at present, be most parsimoniously attributed to incidental long distance or down-the-line exchanges with people not only in the Midwest, but also further south. To the extent that these distinctive types of material interaction are separated in space (i.e., between monuments) and time (discussed below), they stand to complement documented historical shifts in monumentality and, in turn, the directionality and nature of Garden Creek's interregional connections.

\section{Dating the Monuments}

Having described the architectural and artifactual characteristics of the Garden Creek monuments, it is now necessary to situate these contexts in time to create a robust historical narrative of the site. Fortunately, Keel's and my own fieldwork yielded numerous charcoal samples that were radiocarbon dated as part of recent investigations at the site. In total, eight new dates were run on wood charcoal from eight different features in Mound No. 2. Based on my reanalysis of field maps, profiles, and sample elevations, some of these features were assigned to different stratigraphic contexts (i.e., pre-mound, primary mound, secondary mound) than they were in Keel's (1976) original formulation. Samples were selected from different stratigraphic contexts throughout the mound to evaluate the duration and tempo of the entire life history of the monument, as well as from several features on the summit of the primary mound, to better date activities occurring across the most intact monumental surface at the site. The individually calibrated dates from these samples are presented in the fourth column of Table 1 . They are in approximate stratigraphic order from latest (top) to earliest (bottom), with the exception of Sample No. GC1966.07, which was recovered from either midden or mound slump and could not be confidently assigned stratigraphic order. Because no stratigraphic relationships could be inferred from the features on the primary mound, they are attributed here to a single phase of mound summit use.

Even in this relatively raw form, the overlap in these dates is considerable, providing a strong indicator that the construction of Mound No. 2 occurred over about two hundred years at the PigeonConnestee phase transition. These results can be 
Table 1. Radiocarbon Age Estimates from Mound No. 2, Garden Creek, Calibrated Using OxCal Version 4.2.2 and Int.Cal 9 Calibration Curve (Reimer et al. 2009).

\begin{tabular}{|c|c|c|c|c|c|}
\hline $\begin{array}{l}\text { Sample No. } \\
\text { (Lab No.) } \\
\end{array}$ & $\begin{array}{c}\text { Feature No., } \\
\text { Description }\end{array}$ & $\begin{array}{c}\text { Stratigraphic } \\
\text { Context }\end{array}$ & $\begin{array}{c}{ }^{14} \text { C years } \\
\text { B.P. }\end{array}$ & $\begin{array}{c}\text { Individually } \\
\text { calibrated } \\
\text { 2-sigma range } \\
\text { (cal A.D.) }\end{array}$ & $\begin{array}{c}\text { Modeled } \\
\text { calibrated } \\
\text { 2-sigma range } \\
\text { (cal A.D.) }\end{array}$ \\
\hline $\begin{array}{l}\text { GC1966.04 } \\
\text { (AA100830) }\end{array}$ & Fea. 40 , basin & secondary mound & $1765 \pm 38$ & $137-382$ & $262-387$ \\
\hline $\begin{array}{l}\text { GC1966.01 } \\
\text { (AA100827) }\end{array}$ & Fea. 5, cobble hearth & primary mound & $1771 \pm 38$ & $240-410$ & $294-341$ \\
\hline $\begin{array}{l}\text { GC1966.02 } \\
\text { (AA100828) }\end{array}$ & Fea. 18 , cobble hearth & primary mound & $1760 \pm 38$ & $139-385$ & $211-334$ \\
\hline $\begin{array}{l}\text { GC1966.03 } \\
\text { (AA100829) }\end{array}$ & Fea. 32, simple hearth & primary mound & $1799 \pm 38$ & $126-337$ & $184-331$ \\
\hline $\begin{array}{l}\text { GC1966.05 } \\
\text { (AA100831) }\end{array}$ & Fea. 41, burned floor & primary mound & $1700 \pm 43$ & $240-425$ & $235-360$ \\
\hline $\begin{array}{l}\text { GC1966.06 } \\
\text { (AA100832) }\end{array}$ & Fea. 43 , cobble hearth & primary mound & $1638 \pm 38$ & $265-537$ & $249-329$ \\
\hline $\begin{array}{l}\text { GC1966.08 } \\
\text { (AA100834) }\end{array}$ & Fea. 45, mica-lined pit & pre-mound midden & $1839 \pm 38$ & $76-312$ & $128-317$ \\
\hline $\begin{array}{l}\text { GC1966.07 } \\
\text { (AA100833) }\end{array}$ & Fea. 44 , cobble hearth & context unclear & $1765 \pm 37$ & $137-382$ & not modeled \\
\hline
\end{tabular}

further refined through Bayesian modeling, which incorporates prior knowledge-in this case, stratigraphy - in the statistical calculation of the absolute dates (Bayliss 2009; Bronk Ramsey 2009). For the present model, a three-stage sequence is postulated, beginning with the pre-mound midden, followed by the primary mound, and ending with the secondary mound. All dates from the primary mound were included in a single phase; although their intra-context contemporaneity should not be assumed, the stratigraphic capping of the primary mound features by the secondary mound are viewed as sufficient evidence they share broad temporal associations. That said, it is important to keep in mind that neither these strata nor their features are being dated directly, but rather pieces of wood contained in those features whose radiocarbon ages may not correspond precisely with the age of the feature (e.g., the "old wood" problem). Therefore, these results should be considered a step in an increasingly precise reckoning of time at Garden Creek, but certainly not the last word.

The results of the model are summarized in the fifth column of Table 1. They demonstrate how a Bayesian approach that uses a priori, stratigraphic information can clip sigmas that are often overestimated by standard calibration. In all cases, this modeled 2-sigma range is notably smaller than that yielded by independent calibration of the dates. The integrity of this modeled precision is supported by the fact that six of the seven modeled dates had good statistical agreement with the a priori parameters (A-values $>60$ percent). The only exception was GC1966.06, with a low A-value of 25.4 percent. Both Keel (in the field) and I (on the basis of maps, notes, etc.) agree that stratigraphic position of Feature 43 (on the top of the primary mound) is secure, so it may be that the sample selected to date this feature is somehow out of context.

These new modeled dates attest to an earlier and more compressed history of Garden Creek Mound No. 2 than has previously been attainable through relative dating methods and the single extant date. The single date from the pre-mound midden (individually calibrated or modeled) supports the inference that features and artifacts in this context date to the late Pigeon or early Connestee phase, likely the second or third centuries A.D. It would appear that both mound building episodes occurred shortly thereafter. The earliest and latest modeled dates for the features in the primary mound are $184 \mathrm{cal}$ A.D. and 360 cal A.D., respectively, indicating a maximum of less than 200 years of primary mound summit use in the early Connestee phase. At a 1-sigma error range, this period of summit activity is reduced to a mere century between 217 cal A.D. 
and $315 \mathrm{cal} \mathrm{A.D.} \mathrm{The} \mathrm{general} \mathrm{accuracy} \mathrm{of} \mathrm{these}$ dates is bolstered by the single modeled calibrated date from the top of the secondary mound (262$387 \mathrm{cal}$ A.D. at 2-sigma, 274-320 cal A.D. at 1sigma) that effectively provides a terminus ante quem for primary summit use. Additional dates are necessary from the secondary summit to fully understand the duration of its use. However, if it was used for the same amount of time as the primary summit, then it is likely that it was a locus for activity mostly, if not exclusively, during the fourth century A.D. This would place the entirety of known platform mound activity at Garden Creek squarely in the Connestee phase.

Three AMS dates were obtained on wood charcoal recovered during our recent investigation of Enclosure No. 1: one from the bottom zone ditch fill, one from the middle of the ditch fill, and one from a piece of charcoal nestled among the cobbles of one of the rock filled postholes that intruded into all zones of ditch fill. These dates were calibrated both independently and through Bayesian modeling using stratigraphic information as a priori knowledge, though as with the mound, the possibility of old wood presents some challenge and the resulting chronology awaits further refinement. As mentioned above, it is presently impossible to say with certainty whether there was any time lag between the deposition of different zones of ditch fill. At present, we have no reason to conclude that there were temporal gaps between the deposition of one zone of fill and the next; in fact, the overlap in the independently calibrated dates from the fill indicate that such gaps are quite unlikely. As a result, the dates from the bottom and middle zones of fill are modeled as a single phase. In contrast, we do know that there was a gap between the deposition of these fills and the deposition of the rocks, mica fragments, and charcoal in the postholes. Before Sample GC2011.04 entered the record, the ditch was not only "erased" with a final zone of fill, but a post had been erected in its place, stood for some unknown period of time, and was then removed. The cobbles and artifacts that replaced the post were packed in such a way that this cannot be considered incidental fill. This date, then, is not temporally associated with the preceding phase and is modeled as the last date in the sequence following the phase defined by dates GC2011.01 and GC2011.02. The plausibility of this scenario is supported by good statistical agreement (A > 60 percent) for all samples in the Bayesian model. The results are listed in Table 2.

The dates obtained from Garden Creek Enclosure No. 1 all cluster in the latter half of the early Middle Woodland Pigeon phase. The tightness of this clustering is especially apparent in the results of the modeled sequence. At the 2sigma level, the infilling of the ditch, the erection and dismantling of the post alignment, and the infilling of the postholes appears to have maximally taken 130 years; at the 1-sigma level, the duration of these activities is further reduced to 80 years, beginning by 29 cal A.D. and ending by $106 \mathrm{cal}$ A.D.

These dates also agree well with two dates obtained from features excavated in the area surrounded by the ditch enclosure. Lacking obvious stratigraphic relationships with the ditch itself, these dates were calibrated independently. Wood charcoal from Feature 8, a small cobble hearth located just inside the westernmost wall of the enclosure, was dated to 74-254 cal A.D. (calibrated at the 2-sigma level). Wood charcoal from Feature 28 , a refuse pit closer to the center of the enclosure, produced an assay of 49-125 cal A.D. (calibrated at the 2-sigma level). Based on these assays, then, it would appear that the activities that took place within the enclosure are roughly contemporaneous with the later period of the monument's life history, including its infilling and demarcation by posts.

At present, we lack a stratigraphic context that corresponds with the time when the ditch was initially constructed and left open, so it is not possible to say how much time elapsed between these events and the ditch's infilling. However, the absence of evidence for soil formation at the base of the ditch suggests that its infilling may have followed quickly on the heels of its original excavation. We also lack excavation data from Enclosure No. 2, directly across from Enclosure No. 1, precluding any chronological assessment of this feature on the basis of artifacts, stratigraphy, or absolute dates. For the present, their identical footprints, orientations, and alignments to each other strongly suggest that they were part of a single architectural design plan, and are thus contemporaneous. 
Table 2. Radiocarbon Age Estimates from Enclosure No. 1, Garden Creek, Calibrated Using OxCal Version 4.2.2 and Int.Cal 9 Calibration Curve (Reimer et al. 2009).

\begin{tabular}{|c|c|c|c|c|c|}
\hline $\begin{array}{l}\text { Sample No. } \\
\text { (Lab No.) } \\
\end{array}$ & $\begin{array}{c}\text { Context } \\
\text { Description }\end{array}$ & $\begin{array}{c}{ }^{14} \mathrm{C} \text { years } \\
\text { B.P. }\end{array}$ & $\begin{array}{l}\text { Individually } \\
\text { calibrated } \\
\text { 2-sigma } \\
\text { range } \\
\end{array}$ & $\begin{array}{c}\text { Modeled } \\
\text { calibrated } \\
2 \text {-sigma } \\
\text { range }\end{array}$ & $\begin{array}{c}\text { Modeled } \\
\text { calibrated } \\
1 \text {-sigma } \\
\text { range } \\
\end{array}$ \\
\hline $\begin{array}{l}\mathrm{GC} 2011.04 \\
(\mathrm{AA} 99141)\end{array}$ & rock-filled posthole & $1952 \pm 40$ & $\begin{array}{l}41 \text { cal B.C. - } \\
\text { cal A.D. } 128\end{array}$ & $\begin{array}{l}\text { cal A.D. } \\
24-135\end{array}$ & $\begin{array}{l}\text { cal A.D. } \\
60-126\end{array}$ \\
\hline $\begin{array}{l}\text { GC1966.02 } \\
\text { (AA99139) }\end{array}$ & middle of ditch fill & $1911 \pm 40$ & $\begin{array}{c}\text { cal A.D. } \\
5-215\end{array}$ & $\begin{array}{l}\text { cal A.D. } \\
9-124\end{array}$ & $\begin{array}{l}\text { cal A.D. } \\
29-107\end{array}$ \\
\hline $\begin{array}{l}\text { GC1966.01 } \\
\text { (AA99138) }\end{array}$ & base of ditch fill & $1919 \pm 46$ & $\begin{array}{l}36 \mathrm{cal} \mathrm{B.C.} \mathrm{-} \\
\text { cal A.D. } 217\end{array}$ & $\begin{array}{c}\text { cal A.D. } \\
4-125\end{array}$ & $\begin{array}{l}\text { cal A.D. } \\
29-108\end{array}$ \\
\hline
\end{tabular}

\section{Discussion}

When the architectural, artifactual, and chronological data from Mound No. 2 and Enclosure No. 1 are considered together, the result is a complex history of Middle Woodland monumentality and interaction at the Garden Creek site as a whole. Following low intensity use of the site during the Archaic and Early Woodland periods (Keel 1976:153), early Middle Woodland peoples excavated two ditches to create enclosures for which there is no local precedent. However, there is a strong resemblance between these features and small geometric enclosures in the Ohio Valley that date to the late centuries B.C. or early centuries A.D. While the initial ditch excavation has not been securely dated, it was purposefully filled in during the first century A.D. This infilling appears to have been rapid, perhaps occurring shortly after the original excavation of the ditch, and was associated with the production of cut mica and crystal quartz artifacts for Hopewellian exchange. While these infilling efforts could have effectively erased any trace of the ditch, its location continued to be marked after it was filled in by a line of large posts. By the early A.D. 100s, however, these had been removed and the holes they left behind were deliberately filled with river cobbles and small artifacts. At this point, the monumental "squircles" at Garden Creek would have been rendered invisible.

By then, monumental activity had shifted slightly to the west, where fairly intensive occupation produced a number of features, structures, and a midden deposit around 150-250 cal A.D. Initial construction of the mound resulted in a summit that was in use for less than a century, most likely during the A.D. 200s. Shortly thereafter, the overlying secondary mound was built and its summit used through the late A.D. 300s. Both episodes of mound construction are associated with a few pieces of Hopewellian material culture, but lack evidence of Hopewellian craft production. What happened immediately after the second episode of mound construction is less certain, though additional stages cannot be ruled out (Keel 1976:86).

In sum, we now have evidence for at least two complex episodes of interregional interaction at Garden Creek, based on unique articulations of monumental architecture and material culture. The first episode, represented by Enclosure No. 1 , appears to have most intensively involved interaction with Hopewell peoples to the north, during the heyday of Hopewellian expression in Ohio. The architectural grammar of the Garden Creek enclosures suggests stronger ritual ties between the Appalachian Summit and the Ohio Valley than have previously been acknowledged. Assuming these enclosures constitute a form of ritual architecture, it stands to reason that there was a formally prescribed method for their design, construction, and appropriate use. The remarkable morphological similarities between the locally unprecedented enclosures at Garden Creek and their counterparts in the Adena-Hopewell core suggest that they were built according to the same specific prescriptions, which presumably required dissemination through face-to-face contact, possibly through ritual specialists. It is difficult to explain this interregional architectural pattern as the result of trickle-down diffusion from the Ohio Valley to the Appalachian Summit.

The remains of cut mica and crystal quartz craft production associated with this enclosure 
also point to ritual connections with the Hopewell core, though in some ways this assemblage raises more questions than answers. On the one hand, the local availability of these raw materials, the relative ease with which they can be manipulated, and the local provenance of the associated ceramic assemblage offer no indication that craft production at Garden Creek was undertaken by anyone outside the local community. On the other hand, the utter lack of finished cut mica effigies or crystal quartz bifaces at Garden Creek suggests that these artifacts were produced for purely nonlocal, possibly Hopewellian consumption. Did traveling Hopewellian ritual practitioners visit the Appalachian Summit, share their architectural prerogatives, and encourage the production of craft objects for use in Ohio? Or, did ceremonial leaders from the Appalachian Summit coordinate the production of mica and crystal quartz offerings, to be carried via pilgrimage to massive Ohio Hopewell ceremonial centers, where they could receive instruction regarding ritual activities and architecture to convey back to the mountains? Christopher Carr (2006:579-580) hints at both of these and similar possibilities in his contextual approach to interregional Hopewell (e.g., vision and power questing; pilgrimage to powerful natural places or ceremonial centers; long-distance buying and selling of ceremonial rites), and though a bit removed in time and space, similar pilgrimage scenarios have recently been proposed for the Late Archaic Poverty Point site (Spivey et al. 2014). In either case, what remains to be more thoroughly investigated is how or why individuals in the Appalachian Summit acceded to participation in Hopewell ceremonialism at all, as crafters or as long-distance pilgrims. Drawing on comparative ethnography, Carr (2006) has begun this project by emphasizing the importance of shamanlike ideology and practices within Ohio Hopewell, but additional work is required to accommodate such active participation of non-Ohio peoples.

Although it is unclear exactly how Appalachian Summit people contributed to Ohio Hopewell and to Hopewell-style ritual at Garden Creek, the infilling of Enclosure No. 1 offers a tantalizing suggestion that such interregional relationships ended abruptly. It may be that infilling of the ditch was simply part of the ceremonial life cycle of the monument, and that it was carried out according to the same ritual architectural prescriptions as its initial construction. It is also possible that the effective erasure of the ditch represents resistance to or rejection of Hopewellian ceremonialism by the local inhabitants at Garden Creek, and in turn, a moment of "culture making" in the Appalachian Summit. This scenario finds some support in the emplacement of posts in the now filled ditch, their subsequent removal, and the filling of the resulting postholes with a unique matrix. Similarly distinctive post setting, removing, and posthole filling has been noted at both Structure 1 below Mound No. 2 (mentioned above), and around the Middle Woodland Biltmore Mound, located less than $30 \mathrm{~km}$ east of Garden Creek (Kimball et al. 2010). In these remains, we may have recovered evidence for a uniquely Appalachian form of Middle Woodland monumentality. If so, its assertion immediately following seemingly intensively involvement with Hopewellian interaction and ceremonialism merits further examination.

The interregional connections apparent in the archaeological record of Mound No. 2 are quite different. Architecturally speaking, Garden Creek Mound No. 2 is best understood as a Kolomoki pattern platform mound, and the associated ceramic assemblage, though dominated by local pottery, included some pottery from adjacent southeastern areas. Together, these patterns suggest involvement with a sphere of monumental and material practice concentrated in the Southeast. On the basis of available data, it is difficult to say if Garden Creek and other Kolomoki pattern mounds shared a ritual architectural grammar as precise as that documented among Hopewellian enclosures, so it is not clear if their construction would have required formal interaction between far-flung ritual practitioners. If, as others have argued (Knight 2001; Lindauer and Blitz 1997), these mounds served as loci for community integration activities, it may be more likely that this mode of monumentality and associated practices spread through more social means. For instance, Carr's (2006:587) assessment that "intermarriage at the scale of neighboring groups could have been a significant factor in the down-the-line spread of Hopewellian practices and ideas" may be just as applicable to the Kolomoki pattern in the Southeast. How, then, can we account for the 
seemingly Hopewellian artifacts recovered from the mound? Given the small quantity of this assemblage as a whole, the lack of associated craft production debris, and complementary lines of evidence for small-scale feasting activities at other Kolomoki pattern mounds, the current interpretation of these objects as exotic tokens signaling the possession of esoteric knowledge and as gifts distributed in communal ceremonies remains viable at Garden Creek.

\section{Conclusion}

In light of this dynamic history of monumentality and material culture at Garden Creek, it is clear that unitary visions of interregional interaction are insufficient to explain the diverse ways in which southeastern communities engaged with nonlocal objects, ideas, and people throughout the Middle Woodland period. As discussed above, even though archaeologists have previously acknowledged that such interactions played out in different ways in different places, most extant models for Hopewellian and other intercultural networks implicitly presuppose their overall historical stability. In seeking to provide sub-continental scale explanations for these phenomena, these frameworks have sacrificed temporal resolution, the consequence of which has been a conceptual divide between the processes of interaction and the people who actually did the interacting.

Detailed site histories, like that offered here for Garden Creek, stand to complement such broad explanatory frameworks. Certainly, widespread material signatures justify investigation of Middle Woodland interaction at the macroscale. Just as certainly, however, the people who contributed to these interactions were dispersed in space and time, not to mention distinguished by diverse linguistic, political, communal, and individual identities. The idea that a single framework for interaction could have subsumed all of this cultural and temporal diversity is not only unrealistic, but also at odds with an historical processual paradigm that views diverse processes of encounter as the driving forces of cultural transformation.

At Garden Creek, instead of evidence for an all-or-nothing mode of interaction, we have ma- terial indicators for several processes of culture contact and culture making: relatively intensive (i.e., face-to-face) interactions between far-flung ritual specialists; more community-scale interactions to facilitate integration and intermarriage; and perhaps the assertion of local culture and identity in resistance to nonlocal influences. We should not expect this exact historical trajectory to map onto the diachronic records of other Middle Woodland sites in the Southeast, but we should not be surprised if these records reveal similarly diverse forms of interaction through time. The processes identified at Garden Creek thus comprise both a locally salient historical narrative and a set of concepts amenable to intersite comparison. In this regard, this study can be used as springboard for developing more nuanced questions about intercultural interaction during the Middle Woodland period and the ways in which diverse human experiences actively constituted the persistently enigmatic phenomena that we have referred to as "interaction spheres."

Acknowledgments. This research was possible thanks to Bennie Keel's meticulous documentation of Mound No. 2, and the University of North Carolina's Research Laboratories of Archaeology's curation of resulting materials, to which R. P. Stephen Davis, Vincas Steponaitis, and Meg Kassabaum provided access. GCAP fieldwork relied on the generosity of the residents of Plott Farm, the expertise and assistance of Tim Horsley and the University of Michigan's Eastern North America Range contingent, and support from the National Science Foundation (Grant No. BCS-1225872), the Griffin Fellowship, and Arts of Citizenship at the University of Michigan. Thank you to Lacey Carpenter for providing the Spanish abstract. This article has benefited from comments and conversation with Robin Beck, Cameron Gokee, Casey Barrier, and Thaddeus Bissett, but any mistakes are my own.

\section{References Cited}

Alt, Susan M.

2006 The Power of Diversity: The Roles of Migration and Hybridity in Culture Change. In Leadership and Polity in Mississippian Society, edited by Brian M. Butler and Paul D. Welch, pp. 289-308. Center for Archaeological Investigations, Southern Illinois University, Carbondale. Anderson, David G.

1998 Swift Creek in Regional Perspective. In A World Engraved: Archaeology of the Swift Creek Culture, edited by Mark W. Williams and Daniel T. Elliott, pp. 274-300. University of Alabama Press, Tuscaloosa.

2013 Social Landscapes of the Early and Middle Woodland Southeast. In Early and Middle Woodland Landscapes of the Southeast, edited by Alice P. Wright and Edward R. Henry, pp. 247-262. University Press of Florida, Gainesville. 
Anderson, David G., and Robert C. Mainfort, Jr.

2002 An Introduction to Woodland Archaeology in the Southeast. In The Woodland Southeast, edited by David G. Anderson and Robert C. Mainfort, Jr., pp. 1-19. University of Alabama Press, Tuscaloosa.

Bayliss, Alex

2009 Rolling Out Revolution: Using Radiocarbon Dating in Archaeology. Radiocarbon 51:123-147

Beck, Robin A., Jr., Douglas J. Bolender, James A. Brown, and Timothy K. Earle

2007 Eventful Archaeology: The Place of Space in Structural Transformation. Current Anthropology 48: 833-860.

Braun, David P.

1986 Midwestern Hopewellian Exchange and Supralocal Interaction. In Peer Polity Interaction and Socio-Political Change, edited by Colin Renfrew and John F. Cherry, pp. 117-126. Cambridge University Press, Cambridge.

Bronk Ramsey, Christopher

2009 Bayesian Analysis of Radiocarbon Dates. Radiocarbon 51:337-360.

Brose, David S., and N'omi B. Greber

1979 Hopewell Archaeology: The Chillicothe Conference. Kent State University Press, Ohio.

Burks, Jarrod, and Robert A. Cook

2011 Beyond Squier and Davis: Rediscovering Ohio's Earthworks Using Geophysical Remote Sensing. American Antiquity 76:667-689.

Byers, A. Martin

2004 The Ohio Hopewell Episode: Paradigm Lost, Paradigm Gained. University of Akron Press, Ohio.

Caldwell, Joseph R.

1964 Interaction Spheres in Prehistory. In Hopewellian Studies, edited by Joseph R. Caldwell and Robert L. Hall, pp. 133-143. Illinois State Museum, Springfield.

Carr, Christopher

2006 Rethinking Interregional Hopewellian "Interaction." In Gathering Hopewell: Society, Ritual, and Ritual Interaction, edited by Christopher Carr and D. Troy Case, pp. 575-623. Springer, New York.

Chapman, Jefferson, and Bennie C. Keel

1979 Candy Creek-Connestee Components in Eatern Tennessee and Western North Carolina and their Relationship with Adena-Hopewell. In Hopewell Archaeology: The Chillicothe Conference, edited by David S. Brose and N'omi B. Greber, pp. 157-161. Kent State University Press, Ohio.

Clay, R. Berle

1987 Circles and Ovals: Two Types of Adena Space. Southeastern Archaeology 6:46-56.

1998 The Essential Features of Adena Ritual and Their Implications. Southeastern Archaeology 17:1-21.

2002 Deconstructing the Woodland Sequence from the Heartland: A Review of Recent Research Directions in the Upper Ohio Valley. In The Woodland Southeast, edited by David G. Anderson and Robert C. Mainfort. Jr., pp. 162-184. University of Alabama Press, Tuscaloosa.

2005 Adena: Rest in Peace? In Woodland Period Systematics in the Middle Ohio Valley, edited by Darlene Applegate and Robert C. Mainfort. Jr., pp. 94-110. University of Alabama Press, Tuscaloosa.

Cobb. Charles R.

2005 Archaeology and the "Savage Slot": Displacement and Emplacement in the Premodern World. American Anthropologist 107:563-574.

DeBoer, Warren R.

1997 Ceremonial Centres from the Cayapas (Esmeraldas, Ecuador) to Chillicothe (Ohio, USA). Cambridge Archaeological Journal 7:225-253.
Eastman, Jane M.

1994 North Carolina Radiocarbon Dates. Southern Indian Studies 43:1-83.

Greber, N'omi B.

2006 Enclosures and Communities in Ohio Hopewell: An

Essay. In Recreating Hopewell, edited by Douglas C. Charles and Jane E. Buikstra, pp. 74-105. University Press of Florida, Gainesville.

Greenman, Emerson F.

1938 Hopewellian Traits in Florida. American Antiquity 3:327-332.

Griffin, James B.

1967 Eastern North American Archaeology: A Summary. Science 156:175-191.

Hall, Robert L.

1997 An Archaeology of the Soul: North American Indian Belief and Ritual. University of Illinois Press, Urbana.

Helms, Mary W.

1988 Ulysses' Sail: An Ethnographic Odyssey of Power, Knowledge, and Geographical Distance. Princeton University Press, Princeton, New Jersey.

Holmes, William $\mathrm{H}$.

1919 Handbook of Aboriginal American Antiquities Part I: Introductory, The Lithic Industries. Smithsonian Institution Bureau of American Ethnology, Washington, DC.

Horsley, Timothy J., Alice P. Wright, and Casey R. Barrier

2014 Prospecting for New Questions: Integrating Geophysics to Define Anthropological Research Objectives and Inform Excavation Strategies at Monumental Sites. Archaeological Prospection 21:75-86.

Jefferies, Richard W.

1994 The Swift Creek Site and Woodland Platform Mounds in the Southeastern United States. In Ocmulgee Archaeology, 1936-1986, edited by David Hally, pp. 71-83. University of Georgia Press, Athens.

Jefferies, Richard W., George R. Milner, and Edward R. Henry

2013 Winchester Farm: A Small Adena Enclosure in Central Kentucky. In Early and Middle Woodland Landscapes of the Southeast, edited by Alice P. Wright and Edward R. Henry, pp.91-107. University Press of Florida, Gainesville.

Keel, Bennie C.

1976 Cherokee Archaeology: A Study of the Appalachian Summit. University of Tennessee Press, Knoxville.

Keith, Scot

2013 The Woodland Period Cultural Landscape of the Leake Site Complex. In Early and Middle Woodland Landscapes of the Southeast, edited by Alice P. Wright and Edward R. Henry, pp. 138-152. University Press of Florida, Gainesville.

Kimball, Larry R., Thomas R. Whyte, and Gary D. Crites

2010 The Biltmore Mound and Hopewellian Mound Use in the Southern Appalachians. Southeastern Archaeology 29: 44-58.

Knight, Vernon James, Jr.

1990 Excavation of the Truncated Mound at the Walling Stie: Middle Woodland Culture and Copena in the Tennessee Valley. Office of Archaeological Research, Alabama State Museum of Natural History, Huntsville.

2001 Feasting and the Emergence of Platform Mound Ceremonialism in Eastern North America. In Feasts: Archaeological and Ethnographic Perspectives on Food, Politics, and Power, edited by Michael Dietler and Brian Hayden, pp. 239-254. Smithsonian Institution Press, Washington, D.C.

Lindauer, Owen, and John H. Blitz

1997 Higher Ground: The Archaeology of North American 
Platform Mounds. Journal of Archaeological Research 5:169-207.

Lynott, Mark J.

2004 Earthwork Construction and the Organization of Hopewell Society. Hopewell Archaeology: The Newsletter of Hopewell Archaeology in the Ohio River Valley 6, No. 1. http://www.nos.gov/history/mwac/hopewell/v6nl/six.htm, accessed February 1, 2013.

Pacheco, Paul J.

1996 Introduction. In A View from the Core: A Synthesis of Ohio Hopewell Archaeology, edited by Paul J. Pacheco, pp.vi-vii. Ohio Archaeological Council, Columbus.

Pauketat, Timothy R.

2001 Practice and History in Archaeology: An Emerging Paradigm. Anthropological Theory 1:73-98.

Reimer, P.J., M.G.L. Baillie, E. Bard, A. Bayliss, J.W. Beck, P.G. Blackwell, and C. Bronk Ramsey

2009 IntCal09 and Marine09 Radiocarbon Age Calibration Curves, 0-50,000 years cal BP. Radiocarbon 51:11111150.

Ruby, Bret J., and Christine M. Shriner

2005 Ceramic Vessel Compositions and Styles as Evidence of the Local and Nonlocal Social Affiliations of Ritual Participants at the Mann Site, Indiana. In Gathering Hopewell: Society, Ritual, and Ritual Interaction, edited by Christopher Carr and D. Troy Case, pp. 553-572. Springer, New York.

Sassaman, Kenneth E.

2010 The Eastern Archaic, Historicized. AltaMira, Lanham, MD.

Sears, William H.

1962 The Hopewellian Affiliations of Certain Sites on the Gulf Coast of Florida. American Antiquity 28:5-18

Seeman, Mark F.

1979 The Hopewell Interaction Sphere: The Evidence for Interregional Trade and Structural Complexity. Indiana Historical Society, Indianapolis.

1995 When Words are Not Enough: Hopewell Interregionalism and the Use of Material Symbols at the GE Mound. In Native American Interactions: Multiscalar Analyses and Interpretations in the Eastern Woodlands, edited by Michael S. Nassaney and Kenneth E. Sassaman, pp. 122-143. University of Tennessee Press, Knoxville.

2004 Hopewell Art in Hopewell Places. In The Hero, Hawk, and the Open Hand: American Indian Art of the Ancient Midwest and South, edited by Richard Townsend, pp. 57-72. Art Institute of Chicago, Chicago.

Sherwood, Sarah C., and Tristram R. Kidder

2011 The DaVincis of Dirt: Geoarchaeological Perspectives on Native American Mound Building in the Mississippi River Basin. Journal of Anthropological Archaeology 30:69-87.

Shetrone, Henry C.

2004 [1930] The Moundbuilders. University of Alabama Press, Tuscaloosa.

Spielmann, Katherine A.

2009 Ohio Hopewell Ritual Craft Production. In Footprints: In the Footprints of Squier and Davis, edited by Mark J. Lynott, pp. 179-188. Midwest Archaeological Center, Lincoln, Nebraska.

Spivey, S. Margaret, Tristram R. Kidder, Anthony A. Ortmann, and Lee Arco

2014 Pilgrimage to Poverty Point? In The Enigma of the Event: Moments of Consequence in the Ancient Southeast, edited by Zackary Gilmore and Jason O'Donoughue. University of Alabama, Tuscaloosa, in press.
Squier, Ephraim G., and Edwin H. Davis

1988 [1848] Ancient Monuments of the Mississippi Valley, Comprising the Results of Extensive Original Surveys and Explorations. Contributions to Knowledge. Smithsonian Institution, Washington, D.C.

Stoltman, James B.

1999 Icehouse Bottom and the Hopewell Connection. Research Notes, Frank H. McClung Museum 17.

Streuver, Stuart, and Gail L. Houart

1972 An Analysis of the Hopewell Interaction Sphere. In Social Exchange and Interaction, edited by Edwin N. Wilmsen, pp. 47-79. Museum of Anthropology, University of Michigan, Ann Arbor.

Walthall, John A.

1985 Early Hopewellian Ceremonial Encampments in the South Applachian Highlands. In Structure and Process in Southeastern Archaeology, edited by Roy S. Dickens and H. Trawick Ward, pp. 243-262. University of Alabama Press, Tuscaloosa.

Ward, H. Trawick, and R. P. Stephen Davis, Jr.

1999 Time Before History: The Archaeology of North Car olina. University of North Carolina Press, Chapel Hill.

Webb, William S., and Charles E. Snow

1945 The Adena People. Reports in Anthropology and Archaeology 6 . University of Kentucky, Lexington.

Wright, Alice P.

2013 Under the Mound: The Early Life History of the Creek Mound No. 2 Site. In Social Landscapes of the Early and Middle Woodland Southeast, edited by Alice P Wright and Edward R Henry, pp. 108-121. University Press of Florida, Gainesville.

2013 Monumental Memes: The Architectural Grammar of Early-Middle Woodland Enclosures in the Southeast. Manuscript on file, Museum of Anthropology, University of Michigan, Ann Arbor, Michigan.

Wright, Alice P., and Erika Loveland

2013 Ritualized Craft Production at a Hopewell Periphery: New Evidence from the Appalachian Summit. Manuscript on file, Museum of Anthropology, University of Michigan, Ann Arbor, Michigan.

\section{Notes}

1. There was no evidence in the geophysical survey results or in excavation of Enclosure No. 1 that the ditches at Garden Creek were accompanied by an embankment. However, their possible existence in prehistory can not be ruled out given the site's history of plowing and grading for residential devlopment.

2. Historically, archaeologists have situated Adena as the chronological predecessor of Hopewell in the Ohio Valley, but recent research has demonstrated that this presumed relationship is not necessarily accurate (Clay 2002, 2005).

3 . These summary results are necessarily preliminary, because these databases derive at least in part from nineteenthcentury maps. Recent geophysical surveys (e.g., Burks and Cook 2011) have demonstated that these depictions in these maps can differ significantly from archaeological realities.

Submitted August 5, 2013; Revised November 22, 2013; Accepted December 2, 2013. 